\title{
The Impossible Dream: The Early Years of The College of The Bahamas
}

\author{
Roger G. Brown \\ Former Registrar, The College of The Bahamas ${ }^{1}$
}

ABSTRACT

Remarks by Dr Roger G. Brown, former Registrar of The College of The Bahamas, Coordinator, Bahamas General Insurance Association, given at the official opening of the Harry C. Moore Library and Information Centre of The College of The Bahamas on April 8, 2011.

\section{INTRODUCTION}

"It can't be done". "It's an impossible dream". Pessimism, cynicism, and indifference were the responses of some Bahamians and non-Bahamians to the 1960s and 1970s struggled to achieve human rights and throw off the yoke of colonialism. Few were the voices to counter the negativity. There were those who believed that women ought not to, and would never get the vote. Others denounced the vision of a sovereign Bahamas, condemning the notion that this country could ever be sustainably self-governing. In the latter instance, many predicted that we would devolve into anarchy without the guiding hand of the mother country. Many of these left The Bahamas and moved to Britain, Canada and Australia. There were those who believed that, as regards education for the majority, the zenith of Bahamian aspiration should be one of the existing public schools: the Eastern, Western or Southern Junior and Senior schools. This was the climate into which this resilient institution called the College of The Bahamas was born.

Yet, while the many condemned, there were those who, though fully aware of the potential for cataclysmic impact, pursued the "impossible dream" with unshakeable conviction. Men and women of courage held fast to the dream of self-determination and the Commonwealth of The Bahamas was born almost 38 years ago. While the acquiescence of the colonial power and the United Nations could convey paper nationhood, a free and viable Bahamas needed so much more to affect a concrete reality. A nation needs institutions of all kinds — institutions for internal and border security; institutions to guide and feed the development of a strong economy; institutions to create a social security net for the inevitable times of challenge.

Obviously, it became clear to the founders that there could be no greater institution for the establishment, well-being and perpetuation of a nation than the establishment of a literate, well-educated, well-trained and reasoning populace. To create this resource, the new nation needed institutions of learning providing for all levels of the educational journey. One of the greatest investments of the independence era was the creation of a significant number of secondary schools to ensure that secondary education would be available to all who would avail themselves of

${ }^{1}$ Roger G. Brown, former Registrar of The College of the Bahamas.

APA reference: Brown, R. G. (2014). The impossible dream: The early years of the College of The Bahamas. The International Journal of Bahamian Studies, 20(2), II 1-11. https://doi.org/10.15362/ijbs.v20i2.215

(C) R.G. Brown, 2014. Journal compilation @ The International Journal of Bahamian Studies, 2014 
the benefit.

Happily, the decision was also taken to make tertiary-level studies readily available to Bahamians onshore. Again the chorus of negativity arose, this time with both covert and overt contempt_- "It can't be done", "Where are the lecturers coming from?", "What kind of college can Bahamians run?" This was to be expected from a people who have been taught to value people and manufactured foreign goods over home-grown products and local creations. Much more daunting was the reaction or, I should say, the non-reaction of the general Bahamian populace.

As I intimated earlier, it takes men and women of courage to press forward on a difficult course in a climate of great pessimism. Fortunately, there were those willing to take up the challenge and in 1974 the new Parliament promulgated the College of The Bahamas Act. COB was launched on December 19, 1974 and opened its doors to students in January of the following year.

I want to pause at this point to thank the College, especially the College Librarian, Ms Willamae Johnson and the planning committee for inviting me to reflect on the early history of the College. History is vital to the identity and viability of an institution. When we fail to remember, we are often called to repeat the errors of the past or do great disservice to those to whom we owe much. One recent example of this in the student publication The Spectrum troubled me greatly. An article on the opening of the new library and information centre in Volume 15, issue 3 (Worrell, 2011), claimed that the decision to build a new library was taken in 2005. By its mention of the names of the current Librarian and her assistants, one would assume the writer had interviewed them and could be trusted to render an accurate account, full of the key details. But it seems we failed in promoting the heritage of the College to such an extent that the writer was unaware that the decision was taken to build a new library for COB many, many years before 2005. There are many names that I can call even now of people who served on a planning committee for a COB Library: Dr Pandora Johnson, Willamae Johnson herself, Patricia Glinton-Meicholas and a number of others. Should the writer not have been told of Dr Pandora's dedicated-long championship of the new library and concomitant hard work, undaunted in the face of many detours and disappointments? What was he not told of the debt we owe to this major donor for his tireless promotion of the library fund; the debt we owe also to College faculty, staff and students who made their monetary contributions as well? I understand that Dr Rhonda Chipman-Johnson, immediate past Executive Vice-President, was the largest single internal donor through her tea parties and walkathons.

Another, and more serious example, of what could happen when an institution fails to preserve its history occurred just recently when we were memorializing our departed friend and the first president of the College, Dr Keva Bethel. It was brought to my attention that all the original College Council files, the files for the Academic and Appointments Boards, and other files covering the first years of the College could not be found. These documents contained the background and structure of the College's staff and faculty appointment policies, admissions policies, financial aid policies, among others. Without them it is impossible for anyone now to explain the rationale for most of the College's current policies and procedures.

Rome was not built in a day, and neither was this institution. Unlike Aphrodite, the College did not spring full-fledged from one person's head. The history of the College did not begin in the year 2000 and I'm happy to have this opportunity to recall some of the highlights of 
the earlier years.

The initiation story is an old one for many, but obviously it bears repeating. When the government decided to move from conceptualizing to concretizing, it was a scramble to source all the elements to create a viable college. First of all, we needed students with the intellectual capacity, the secondary preparation and the drive to undertake tertiary-level education and instructors capable of inspiring them to make the mental leaps. We also needed the leadership with tertiarylevel academic experience, and we needed facilities. The very small size of the Bahamian population and the limits of the national budget were just two of the factors militating against the success of the venture.

What we also needed, and were not given, was time to adequately plan for the launching of the venture. The Government had decided that the announcement and the creation of the College would coincide with Independence and therefore took the route most likely to achieve the desired destination by pulling together institutions that were already offering foundations of college-level studies. It was thus that they created a body for the College of The Bahamas, amalgamating the C.R. Walker Technical College, the Sixth Form programme of The Government High School, the Bahamas Teachers College and the San Salvador Teacher's College.

For leadership, Dr John Knowles, a Bahamian professor at Simon Fraser University in Canada, was invited to be principal and $\mathrm{Dr}$ Dennis Meakin, a Canadian, was appointed Registrar of the fledgling institution. The names of many of the lecturers from the early years are instantly recognizable today, as persons who have contributed greatly to the building some aspect of our society-among the Bahamians such as our late colleagues Portia Smith, Marguerite Martin, Thelma Gibson, Corinne Thompson and Keva Bethel.
There were also Eleanor Thompson, Alvan Rolle, Dorothy Gardiner, Pandora Johnson, Haldane Chase, Ellen Serville, Claire Hepburn, poet Robert Johnson, Dorothy Yearwood, Paula Sweeting Davis, cultural advocates Arlene Nash Ferguson and Patricia GlintonMeicholas and Rhonda Chipman-Johnson. There were others whose navel strings may have been buried elsewhere but gave unstinting service. I recall Harold Mentel, Ken Warhurst, Claire Belgrave, Neal Nezamuddeen, Neil Sealey, Pearl Monaghan and the late, lamented Pauline Glasby. This is not a roll call by any means; the list of contributors would take up a few hours, but named or unnamed, I pay tribute to all. At some point there should be a wall of memory, lest we forget.

There were those who pioneered new programmes. I remember Cecile Knowles, Jennie Isaacs, and Ernestine Douglas, stalwarts of nursing. I must make special mention of those pioneers of the Family Island centre that I can recall: Arthur Roach and the late Sylvia Darling should be remembered for pioneering the Freeport Campus. They laid the foundations, but I fear no contradictions when I say that Dr Coralee Burrows Kelly created the habitable, viable centre and programme that has grown and has contributed much to manpower development in Grand Bahama. I remember the trials of sharing an already inadequate facility on Pioneers Way in Freeport with the Bahamas Technical and Vocational Institute.

There were many Bahamians and nonBahamians who came from every continent to serve with intelligence and fidelity in the early years. Some not only served as midwives at the birth of the College but saw it through potty training, kindergarten, the falls, the scraped knees and bloody noses, the internecine fights, the disappointments and triumphs great and small, and the frequent wrongheadedness of adolescence and the 
many unanticipated challenges of early adulthood. This latter stage is where I believe COB to be today.

I was part of the contingent from the Bahamas Teachers College and had been identified by the Ministry of Education from the outset to become part of the administration of the new college. Right at the beginning of the formative period, in the summer of 1974, I was awarded a one-year Canadian-government fellowship to pursue a master's degree in higher education administration at the University of Toronto in Canada and later an OAS Fellowship to undertake doctoral studies in the same area. When I returned to the Bahamas with my master's degree in the summer of 1975 , I discovered that no place had been made for me at COB. Communications between the Ministry of Education and Dr Knowles seemed to have gone awry but eventually Mr Baltron Bethel, the formidable Bahamian who was Permanent Secretary in Education at the time, intervened and I was named Registrar-designate in December 1975. I can only assume that this did not sit well with the then Registrar because my advent was marked by his almost immediate departure by resignation about four months later in April of 1976. College administration took a double blow because, for reasons, which he never disclosed to me, the principal, Dr John Knowles, also resigned and left the COB in the same month as Dr Meakin. What I will say is that these men made a necessary and valued contribution to the College during those first few years.

To understand and appreciate their contribution it is necessary to recall the events of the period following the promulgation of the COB Act, 1974. The specific purpose of the Act was to implement the Government's new higher education policy as was outlined in the White Paper entitled Focus on the Future (1973). The plan envisioned a single multipurpose institution, which would be the apex of the system of primary and secondary education to meet the special needs of the country in education, training and cultural development. This was different from previous policy in which opportunities for further and higher education had been provided in several separate post-secondary institutions: Bahamas Training College and San Salvador Teacher's College for teacher training, C. R. Walker Technical College for technical and vocational training and Government High School for academic programs.

The 1974 Act was passed and promulgated in early 1974. The College was officially launched in December 1974 and opened its doors to students in January 1975. However, as no time was given for proper planning, the different institutions continued to operate as separate units until an integrated structure and certain semester-length academic programs were operationalized in September 1975.

Drs Meakin and Knowles were thus responsible for the initial transition from a traditional British academic structure, with year-long courses divided into three terms, with one initial intake of students, and one exam at the end of the year, to a semester system of two or three intakes of students with advisement and registration and examination sessions - all done manually and while the pre-existing teacher education programmes, the C. R. Walker technical programmes and the Government High School A-level programmes continued. And did I mention that this was before computers?

I was made Registrar upon Dr Meakin's departure and although no formal announcement was made, and no extra remuneration was given to me, I had to assume the additional role of Acting Principal while an intense search for a principal was initiated. I can report with pleasure that the search was not driven by political expedience 
but by the desire to secure the right combination of scholarship, administrative talent, personal conviction and drive.

Dr Kazim Bacchus, who was originally from Guyana, and who had come out of the Commonwealth Secretariat in London, took the helm. His was the task of directing the cementing, riveting and cladding of the skeleton that the first administrators had but in place. The responsibilities entailed finalizing the amalgamation process and the legal arrangements regarding the status of the faculty and staff of each of the four contributing institutions. It had to be decided who would remain with the Ministry of Education and who would enter the brave new world of the newborn establishment. There were also the material and physical aspects of the work: closing BTC and transferring people and equipment to the present campus and closing the facilities, as well as transferring people and equipment from San Salvador for example. The process was heavily charged with psychological challenges - it was necessary to convince people who were used to having their own spaces and working in long-established teams to build anew.

Unbelievable as it may now seem, the biggest conundrum was exactly what form the College should take. Many strong views were put forward-Secretary to the Cabinet, Rodney Bain, was adamant that an A-level institution should be developed. Government policy, however, was diametrically opposed to giving primacy to an academic core. On the other hand, certain influential Cabinet members made manpower development the priority and the College was thus required to focus on technical and teacher training with a lesser emphasis on academic studies for transfer to universities abroad.

In her doctoral thesis in education, Dr Eleanor Thompson (1983) noted that the Government's expectations for the College were perhaps too high, especially considering the resources allocated to the institution, and that by 1979 certain members of the Cabinet were questioning whether or not the policy had to be changed. It had been expected that the College would bring about an increase in the number of graduates in the various targeted areas: that there would be increased production of technicians of various types and levels; and that the supply of trained teachers for the expansion of the school system would be increased. However, by 1979 it had become evident that this was not happening.

What the legislators wanted of the College was clearly a response to the economic and social climate of the times and the need to decolonize. A burgeoning economy driven by tourism and a growing financial services sector created an increasing demand for skilled and well-trained labour. At the same time, Independence saw the departure of the colonial administrators and many of the expatriates who had filled the majority of leadership positions in business and industry. The desire to define and fix a national identity and the enunciation of a Bahamianization policy made the need for skilled labour and Bahamian managers more urgent.

In the 1974/75 academic year, the total enrolment in the two teachers colleges was 527, with 182 graduates in 1975. By 1979 the number of trained teachers produced by $\mathrm{COB}$ totalled 83. In 1974/75 the enrolment in the technical and vocational areas was 2299 in fulltime, day-release and evening programmes. In 1979 there were only 28 graduates from the Division of Technology, 59 from Business Administration, and 31 from Applied Sciences.

What would prove to be a further retardant of progress in the life of the institution before the advent of the 1995 Act was the College's restrictive administrative and funding structure, which was tied to the ironclad hierarchical bureaucracy of the Ministry of 
Education, the Ministry of Finance and the Treasury, that was left over from the colonial period. To demonstrate, it is enough to say that the College Council, which was responsible for all aspects of the governance of the College, was appointed by the Minister of Education. By the terms of the Act of 1974, the Council was mandated to "comply with any directions given by the Minister" (College of The Bahamas Act, 1974).

Dr Thompson also noted in her dissertation that:

The financial provisions of the College of the Bahamas Act (1974) provided for the College to be funded out of the Consolidated Fund. The implication of this was that the funds for the College would have to be voted annually by the legislature and that the College would have to compete for its share with other parts of the education enterprise as well as other national concerns. Additionally, the stipulation in the Act that all College expenditure be controlled by the Minister of Finance meant that the College would be subjected to the same treasury fiscal control procedures as the government departments. Such fiscal control was likely to cause serious constraints upon the ability of the College to function with effects being felt most sharply in the areas of capital and operating budgets and the authorization of contracts and purchases (1983, p. 102).

Also problematic was the mismatch between College requirements and the achievement of students from the feeder public schools. It put incredible demands on the faculty, who were called upon to teach A-level, university bound students, as well as those whose literacy was tenuous. This conflict resulted in programmes like the famed Transitional Education or "TransEd" and later the College Preparatory programme.

In the beginning, elements of faculty working conditions had proved attractive to those who had come out of the public school system to form the early College academic team. Salaries were better and hours were better. I'm sure that the present faculty would scoff, if reminded that the base salary and class contact time were $\$ 12,000.00$ and 16 hours, respectively. The outlook changed fairly rapidly and in 1978, just three years after The College opened, the Faculty sent a formal report on conditions that they considered inconsistent with the goals set for the institution.

Dr Thompson who gave far too much to build COB to be forgotten, was very much involved in protesting the difficult conditions and noted in her thesis:

What appeared to be adequate incentives when the College was first started, turned out to be insufficient once people were actually working in the College. The COB faculty members now had a wider range of responsibilities than before. They were required to design courses, prepare different kinds of lectures for different types of people and take on advisement and registration duties. In some divisions such as Business Administration where faculty were increasingly being required to teach mostly at night (because working people constituted the majority of students) they resented the interference with their private lives. Many resented the loss of the long summer holidays, which they had enjoyed in the former colleges (1983, p. 155).

It was absolutely certain that the conditions of service and physical plant were sub-par for an institution calling itself a college, but the situation was exacerbated by the fact that there were those who could not embrace change and did not understand or accept the challenges that come with building a nation. One of the faculty members whom Dr Thompson interviewed in the summer of 1982 
thought "it wrong to have such a short break" referring to the five-week summer break.

As the 1970s was the age of Independence and decolonization we would see activist movements, sit-ins, and self-actuation, being used in the Bahamas and other parts of the world to show dissatisfaction with the status quo. Moreover, Bahamians were still riding high on the success of the struggle for majority rule and Independence, struggles which had, in turn, drawn strength from the 1942 riots and the 1959 general strike. So in early 1978, a group of COB faculty and students marched on Rawson Square to vent their frustration over the confusion in the College. This way of solving problems seems to have been adopted as the methodology of choice as the years advanced.

One of the brightest innovations of this era was the launching of the Faculty/Staff Development Programme in 1976. By the mid-eighties the scheme had underwritten study leaves for a score or more of the College team members in pursuit of master's and doctoral degrees.

Dr Kazim Bacchus brought a great deal of structure to the wild frontier that was the $\mathrm{COB}$ in those early days. He was a political animal who knew how to negotiate difficult passages with government, faculty and staff and members of the public. He also possessed valuable international contacts, which he harnessed for the benefit of The College. If I were asked to identify Kazim Bacchus's most lasting contribution, I would have to say the relationships he helped to forge between $\mathrm{COB}$ and a number of international universities, which included institutions in Canada, the United States and the University of the West Indies.

In the latter instance, we secured a collaboration that has yielded great benefits for our people and our education system. It was at that time that the Joint Board of
Teacher Education was established, which extended the opportunities for in-service professional training to Bahamian educators. Through this programme they received certification, which bore the imprimatur of a highly respected academy. The COB would derive many benefits from its association with UWI over the years, as evidenced by the Bachelor of Laws programme, which started in 2000 .

Dr Jacob Bynoe, a professor from the University of Guyana, became the next Principal of the College of The Bahamas. Dr Bynoe was a very reserved man, but proved to be a leader of great substance for a college in development. He was a scholar of note who was able to get faculty to focus on shaping the academic core and thus advanced programme development. It was during his tenure that the Hotel Management programme was initiated and the Business and Technology buildings were constructed. The College was honoured when, in 1985, Her Majesty Queen Elizabeth II took part in the official opening of the new facilities. I wonder if the monument she unveiled still exists.

Dr Bynoe served for four years, completing two contracts. Keva Bethel, then Academic Dean, was viewed as his successor and sent to the University of Edmonton in Alberta, Canada do a special accelerated Ph.D programme. She returned to be appointed Principal and Dr Eleanor Thompson was appointed Vice Principal. As is now wellknown, Dr Bethel served as leader of the College for 20 years. In 1995 when the new College of the Bahamas Act was passed, bringing the College autonomy, she was appointed its first President. Dr Thompson had already retired and I was appointed Executive Vice President, Alvan Rolle, Bursar, and Joyce Thompson, Academic Dean. Inez Peet would direct the Continuing Education Division. Dr Bethel never failed to acknowledge that she was no one-woman 
army, but the achievements of her tenure were the achievements of a close-knit and mutually- supportive team.

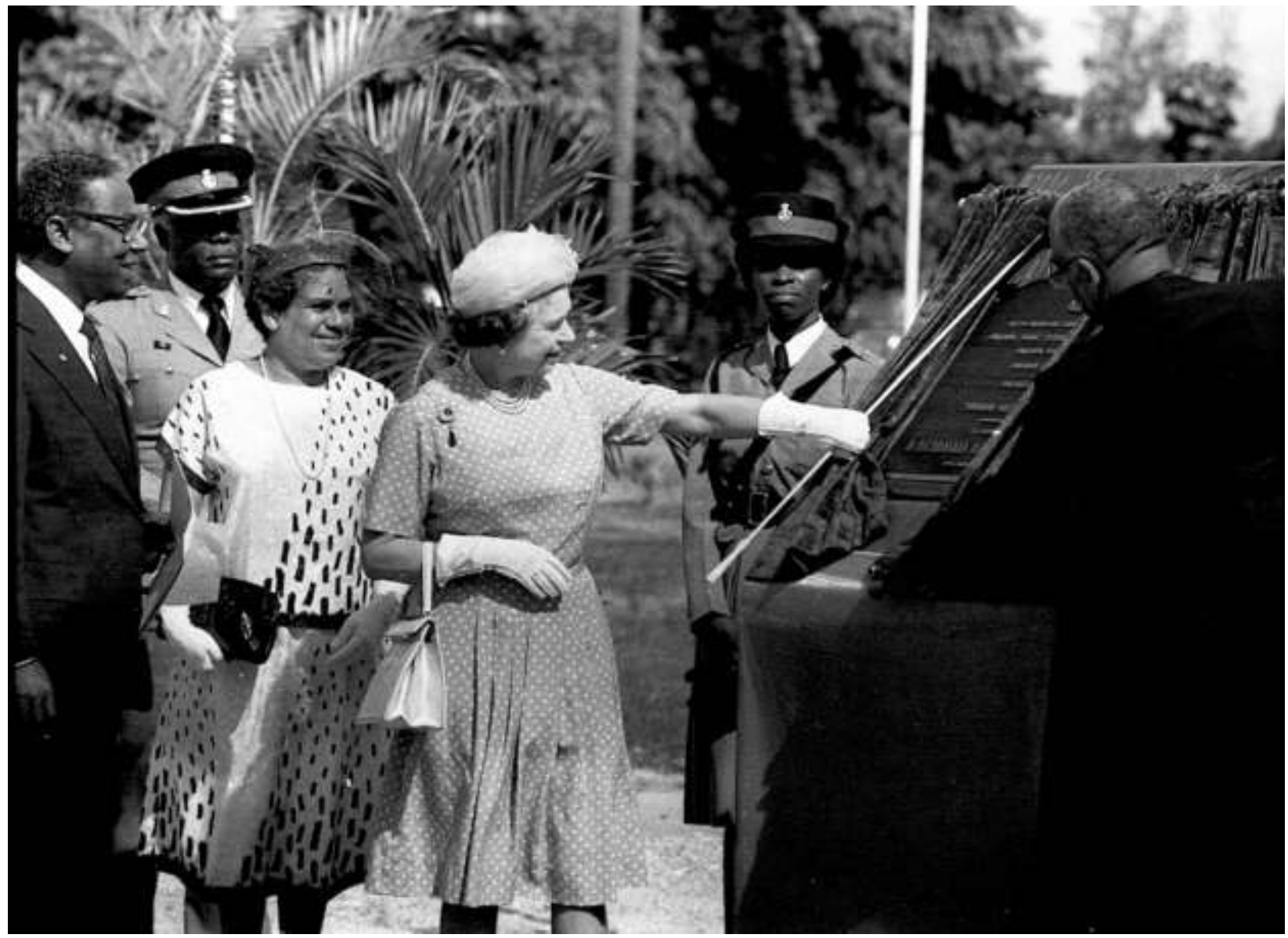

Figure 1: H.M. Queen Elizabeth. 1985.

A number of significant goals were set and achieved around this period, one of which was a drive for articulation agreements and collaborative initiatives with long-established and respected tertiary institutions. I recall visiting several Canadian universities for this purpose. It was around this time that we forged a pact with George Mason University to establish the research centre on Andros, assumed responsibility for the Research Centre of the Fingers Lakes Consortium that evolved over time into the Gerace Research Centre. It was so named to justly honour Dr Donald Gerace, who with his wife Kathy, helped to impress the Centre on the international research consciousness as a desirable base for serious researchers in such fields as archaeology, ethno-botany, and the study of terrestrial and marine waters.

The Exuma extension programme also came into being in this period, challenging faculty and administrators to devise new ways of delivering programmes and to deal with yet more facilities constraints. Despite it all, things happened, faculty taught and students achieved. I'm sure that faculty members like Janet Donnelly could provide chapter and verse of this story. We must be grateful to these pioneers, the Ministry of Education for affording COB space in its Resource Centre in George Town, the Benjamin Foundation, 
which donated the facility and Jenny Kettel who, with her husband Chris, has run it for so many years. As time went on, programmes were extended to Abaco, Andros and Eleuthera: some academic and some technical and vocational.

The mid-to-late-1990s were marked by a considerable expansion of the administration with the creation of several vice presidencies and deanships. As with the promulgation of a new Act of Parliament, this development was a prelude to achieving the ultimate prize - the declaration of the University of The Bahamas. It was also the era of the flourishing of the Union of Tertiary Educators of The Bahamas (UTEB), but in contrast, a faculty senate did not materialize and has still failed to shoot above the hardened soil of partisan resistance and an obdurate, retrograde mindset.

I left the College in 1995, not long after the promulgation of the new College of The Bahamas Act. You might say that I saw the prophetic handwriting on the wall, foretelling many of the rough passages that have tended to define the 21st century College-the leadership crisis, the seemingly constant standoff between Administration and the faculty union. The brave starts and the often puzzling stops of any number of vital programmes: the Poultry Project, underwritten so generously by the Freedom Foundation of the Campbell Trust, the Marine \& Environmental Sciences Institute and other less egregious start-ups.

In this 37th year of its existence, the COB has much more to show and boast as regards its contribution to helping Bahamian talent to flourish and consequently, its contribution to national development. You have graduated students, either from the early A-level programme or from certificate, associate degree, diploma and first and second degree programmes who have become movers and shakers in every economic sector, in every profession and in every branch of society in this country. The names of a growing number of your graduates are resounding in the international arena for brilliance and accomplishment in their fields. That is no mean feat and I congratulate you on this nation-changing achievement. I think that there are those among you and colleagues past, whose footsteps on the sands of COB should be cast in bronze and set up as monuments in memory of their stellar input and sacrifices. It is not my job to name them, however. I leave that to those who continue to serve.

It is a fact of life that the struggles, miscalculations and mishaps often mark human progress when we pioneer into the unknown. Bringing disparate elements together in any kind of amalgamation is like organ transplantation. You are forcing different DNA to work together to form a new unit and we know that preventing adverse reaction is often the business of a lifetime. If the COB is to become the best it can be, we are always going to be dealing and thinking out of the box. Despite what those who misunderstand the concept of Bahamianization many think, we will always have to have the injection of DNA from a variety of sources. I would go so far as to say we have to plan for and invite variety-without it a dangerous insularity results, putting limits on the institution's creative power.

There are undoubtedly Bahamians of great ability and even Bahamians of extraordinary genius. We must identify them, groom them specifically for the roles they are to occupy and provide sufficient inducements, such as decent facilities, the best tools, the best libraries, the best laboratories, the best spaces to boost and engender the flourishing of the arts. And we must never neglect competitive emoluments to keep them productive and happy.

This brings me to faculty and staff 
representation-especially the ways in which you represent yourselves in the world of scholarship and how you are represented in gaining and sustaining rights. I am convinced that the State of Wisconsin in the United States has made a mistake with its recent legislation on short-circuiting the collective bargaining process. All groups need representation. To secure the well-being and longevity of the body represented, however, it must be good and appropriate representation. It must be specific to the unique characteristics, occupation and developmental needs for the group for which it has agency. I believe that the Union of Tertiary Educators of the Bahamas should educate even as regards industrial relations. It should lead and devise new industrial practices that demonstrate a keen understanding of the nature of the Bahamian economy and society. The membership should be contributing new pages to the body of literature on intelligent conflict resolution. You should be the faculty guild that so promotes excellence in your ranks that your stamp of approval should secure places at the most august centres of learning for those you recommend.

Now there is only one more matter that I wish to touch upon before I sit down. In the move to create the University of the Bahamas, what is to become of our other university of the Bahamas, the University of the West Indies? Does the College of the Bahamas see itself developing a close relationship with UWI, into which this nation has poured and continues to pour so much money and which has produced so many doctors, lawyers, teachers, engineers and other trained persons for the country? Does it make any economic sense to ignore the existence of UWI while endeavouring to create a University of the Bahamas?

College of The Bahamas-aspiring University of The Bahamas - the time has come to dream again. It is time once again to endure the scoffing of the crowd that is sure to come, time once again to make the sacrifices and shed the tears that are the price of extraordinary accomplishments. Time to plant the vision that will spur Bahamians to actively seek the grandeur and the fame that are inherent in this institution and that will stand as an eternal tribute to the formidable sacrifices made to build it and bring it to this day. It is time to scrape away the dross that has settled on its walls with the passage of time.

Great universities are not built on claims of greatness but on evidence of pioneering thought and works. It is therefore time to reveal the patina not of age but of a maturity characterized by excellence in scholarship and discovery, in instructional practice, publication and creativity that true scholars and people of discernment and goodwill everywhere will recognize, praise and even celebrate. 


\section{REFERENCES}

College of The Bahamas Act, Chapter 37, Bahamas, 1974.

College of The Bahamas Act, Chapter 48, Bahamas, 1995. Retrieved from http://www.cob.edu.bs/DOCS/COBACTN O15_1995.pdf

Ministry of Education and Culture. (1973).

Focus on the future: White paper on education. Nassau, Bahamas: Author.

Thompson, E. M. (1983). An examination of the implementation of higher education policy in an independent Bahamas, 19741982. (Unpublished doctoral dissertation). University of Toronto, Ontario, Canada.

Worrell, B, (2011). Harry C. Moore Library finally opens! The Spectrum, 15(3), 1, 10. Retrieved from http://dloc.com/CA03399630/00018 